\title{
Sensory and Physicochemical Analyses on Commercial Taro Ice Products
}

\author{
TING-JANG LU ${ }^{1}$, CHIH-WEN CHUANG ${ }^{2}$ AND YUNG-HO CHANG ${ }^{2 *}$ \\ 1. Graduate Institute of Food Science and Technology, National Taiwan University \\ 59, Lane 144, Kee-Lung Road, Sec. 4, Taipei, Taiwan 106, R.O.C. \\ 2. Department of Food and Nutrition, Providence University \\ 200 Chung-Chi Road, Shalu, Taiwan 43301, R.O.C.
}

(Received: June 19, 2001; Accepted: November 2, 2001)

\begin{abstract}
Fourteen commercial taro ice products, including 8 ice-bar products and 6 ice-cream products, were used as the samples in the present study. The physicochemical properties of the commercial taro ice products such as color, moisture content, fat content, overrun, viscosity, texture, melting rate and free-sugar composition were measured. Sensory evaluation and principal component analysis (PCA) methods were also employed to investigate the important sensory factors. Results indicated that the ice creams showed lower levels of differences in color and higher overrun values, whereas the ice bars had a higher value of hardness and lower melting rate. Sucrose and lactose were the major free-sugar components for most of the commercial taro ice products studied. Ice-bar samples showed a significantly $(\mathrm{p}<0.05)$ higher value of firmness in sensory evaluation, and the sweetness and creaminess scores of ice bars were less diverse than those of the ice creams. Results of PCA indicated that the sensory evaluation method distinguished the differences between the ice cream products in a more sensitive manner than that of the ice-cream products. The significant $(\mathrm{p}<0.05)$ attributes of the sensory evaluation to the first principal component of ice bars were sweetness, thickness, firmness and color whereas fattiness was the significant $(\mathrm{p}<0.05)$ item to the second principal component. For the ice creams, on the other hand, the significant $(\mathrm{p}<0.05)$ sensory evaluation items were color, creaminess, sweetness, thickness (for the first principal component), overall score and taro flavor (for the second principal component). Based on the results of PCA, the evaluation of sweetness, color and thickness were the important sensory factors, which then could be used as a reference index in the development of taro ice products.
\end{abstract}

Key words: taro ice products, commercial products, sensory evaluation, principal component analysis

\section{INTRODUCTION}

The frozen dessert market has grown rapidly in recent years and become one of the important consumer products without seasonal restrictions. Among the traditional ice products, taro ice products have a unique flavor, smooth texture and special color that are especially appreciated by Taiwanese consumers. Based on the properties of the finished products, taro ice products can be classified into two categories, namely, ice bars and ice cream. Generally speaking, the principal components of ice cream are fats (8-20\%), sugars (13-20\%), stabilizers/emulsifiers (0-0.7\%), and total solids $(36-43 \%)^{(1)}$. Compared to other ice products, the fat content and overrun property of ice cream are greater than other ice products. According to the definitions and standards of identity published by the US Food and Drug Administration (FDA), an ice product has to be comprised of at least $10 \%$ of butterfat and $20 \%$ of total milk solid to be called as ice cream ${ }^{(2)}$. The ice cream can be labeled "reduced fat", "low fat", or "non fat" when its total fat content is lower than $10 \%$ as desired by the market. The Chinese National Standard (CNS) defines that butterfat-containing ice cream has to consist of equal or greater than $8 \%$ of butterfat and

\footnotetext{
* Author for correspondence. Tel: 04-26328001 5302;

Fax: 04-26318407; E-mail:yhchang@ pu.edu.tw
}

greater than $30 \%$ of total solid content, whereas the butterfat and total solid content have to be in the range of 2 to $8 \%$ and greater than $28 \%$, respectively, for ice bar products ${ }^{(3)}$.

Commonly seen commercial ice-bar products can be further categorized into two types depending on their outer appearances. One type is bar-shaped, also known as popsicles. The unit weight varies with brands, but usually is about $80 \pm 5 \mathrm{~g}$, although unit weights up to $120 \mathrm{~g}$ can be seen in the market. The other type is small cube-shaped with unit weight in the range of 20 to $25 \mathrm{~g}$. There are no standards that regulate the composition of cube-type ice bar products, but usually the fat content is lower. Moreover, the manufacturers place more emphasis on the development of new flavors so that the life cycle for cube-type ice bar products is short which in turn has an impact on the prices. Therefore, the goal for future development is to focus on the quality improvement in order to meet the consumer's demand for finer products $^{(4)}$.

The content of milk fats, types and quantity of sweeteners, product overrun, and special flavors are the determining factors of the sensory properties of ice products ${ }^{(5)}$. Although the uses of artificial sweeteners can substitute sucrose for sweetening purposes, they can only partially substitute the properties presented by butterfat. However, the shortcomings of the substitution significantly affect viscosity, melting rate and resistance to deformation of the ice products. 
Sucrose represents the majority of the sweeteners used in ice products, and has become the standard of relative sweetness for other sweeteners. Recently, many ice products have turn to other sugars such as fructose, corn syrup, honey, or maltodextrin to reduce the dependence on sucrose and to adjust the sweetness, freezing point, and solid content ${ }^{(6-8)}$. Nevertheless, glucose, sucrose and maltose are the primary compositions for these sweeteners.

The moisture content ${ }^{(1)}$, content and type of sugars ${ }^{(6-8)}$, and fat content ${ }^{(6,8)}$ of the ice cream are the major factors influencing how the ice cream is perceived by consumers. The creaminess and butteriness of vanilla ice cream increase, while the melting rate and the ratio of ice crystals decrease, as the content of butterfat increases within the range of 3-12\%. The sugar content enhances the sweetness and caramel flavor, but reduces the milkiness ${ }^{(9)}$. Guinard et al. investigated the correlation between physiochemical properties and sensory evaluation by multivariance analysis and found that the strength of vanilla flavor, creaminess, fattiness and milkiness positively impact the consumer acceptance of a product whereas the shades of color, amounts of ice crystals and the hardness measured by the texture profile analyzer impact the acceptability in a negative manner ${ }^{(10)}$. Statistical analyses by linear regression showed that 10 of the analyzed physiochemical properties significantly predicted the results obtained from the sensory evaluation $(\mathrm{p}<0.05)$. In contrast, only the milky taste of the texture properties reflected the outcomes of sensory evaluation at statistically significant level $(\mathrm{p}<0.05)$.

There are limited research reports concerning ice products in Taiwan, of which even fewer are specifically discussed on taro ice products. More research is needed for quality improvement and product development of taro ice products. Furthermore, factors that affect the quality of ice products are complex and hard to control while improving and/or developing new products. As a consequence, the present study analyzed the compositions of market available taro ice products on the market and conducted a comparative assessment on physiochemical properties and sensory evaluation in order to find the correlations. Additionally, the Principal Component Analysis (PCA) was applied to explore the impact factor of each sensory evaluation attribute by multivariance analysis ${ }^{(11)}$, in order to serve as references for future development of similar products.

\section{MATERIALS AND METHODS}

\section{Materials and Pretreatments}

Assorted market available taro ice products of different brands produced by different manufactures were purchased from various supermarket chain stores within a 30-min driving distance to Providence University, Shalu, Taiwan. Three liters and at least $2 \mathrm{~kg}$ of ice cream and ice bar, respectively, were sampled. The ice product samples were placed in polyfoam thermoboxes upon obtaining and transported to be stored at $-20 \pm 1{ }^{\circ} \mathrm{C}$ in a freezer within $30 \mathrm{~min}$. The senso- ry evaluation, texture profile analysis, and physicochemical measurements of color, melting rate and overrun were performed $16 \mathrm{hr}$ after receiving the samples.

\section{Analytical Methods}

\section{(I) Sensory Evaluation}

The panelists for sensory evaluation were screened by the Triangle test for their sensitivity to flavors and textures ${ }^{(12)}$. Those appeared to be more sensitive to different tastes were selected for further training which provided opportunities for repeated comparisons and panel discussion, and ultimately to achieve panel agreement on the standards of scoring. Twelve panelists who demonstrated higher discriminatory ability and consistency to others were chosen to form the panel to perform the sensory evaluation. The panelists had to reach agreement as a group with respect to their perceptions on the sensory properties ${ }^{(13)}$. The sensory evaluation was repeated twice and was rated on a 9-point numerical scale for each of the descriptive attributes. The items and intensities for each item included for evaluation were firmness (the level of firmness at the first bite of the taro ice products, very soft to very firm), taro flavor (the natural flavor of taro, very weak to very strong), sweetness (the sweetness tasted from the taro ice products after melting in the mouth, very light to very sweet), color (the natural purple color of taro, very light to very dense), creaminess (the ice crystals sensed from the taro ice products in the mouth, very rough to very smooth), thickness (the thickness felt from the taro ice products after melting in the mouth, very thin to very thick), fattiness (the fattiness sensed from the taro ice products in the mouth, very light to very greasy), and overall score (the overall liking to the taro ice products from the panelists, very poor to excellent).

\section{(II) Texture Profile Analysis (TPA)}

A stainless cylinder $(6.0 \mathrm{~cm}$ inner diameter, $2.5 \mathrm{~cm}$ height) was used to sample the ice products. The samples were kept at $-20 \pm 1{ }^{\circ} \mathrm{C}$ and the temperature of the test environment was maintained at $15 \pm 1^{\circ} \mathrm{C}$. The samples were analyzed by a texture profile analyzer (TA-XT2 Texture Analyzer, Stable Micro System Ltd., England) which imitates chewing action within a 3-min completion cycle. The procedures of analysis were as follows: mounted the sample onto the sample platform, compressed twice with P/3 cylinder probe (3 mm diameter) to $50 \%$ of its original depth at 2 $\mathrm{mm} / \mathrm{s}$ rate. The analytical texture profile curve of the individual taro ice product was obtained and the dimensional parameters were calculated ${ }^{(14)}$. Five measurements were obtained for each sample.

\section{(III) Color}

The colors of the taro ice products were analyzed by colorimeter (STC-1, Tokyo Denshoku Co., Japan). Values taken 
were Hunter L (brightness), a (+a, red spectrum; -a, green spectrum), and b (+b, yellow spectrum; $-b$, blue spectrum). The following equation was used for the calculation of the color index $(\mathrm{E})$.

$\mathrm{E}=\left(\mathrm{L}^{2}+\mathrm{a}^{2}+\mathrm{b}^{2}\right)^{1 / 2}$

Each ice product was sampled 3 times and measurements were made in duplicate.

\section{(IV) Moisture Content}

According to the method described in $\mathrm{AOAC}^{(15)}$ 16.313, each sample was measured five times.

\section{(V) Crude Fat Content}

Method described in the AOAC ${ }^{(15)} 16.316$ was adopted. Five measurements were taken from each sample.

\section{(VI) Viscosity}

A fixed volume of taro ice product sample was placed in a 100-mL beaker and let stand until completely melted. Four hours after melting the viscosity was measured by a Brookfield viscometer (model LVTDV-DV II, Brookfield Engineering Lab., Inc., USA) at 12-rpm rotating rate under room temperature. Each taro ice product was sampled 3 times and measured in triplicate.

\section{(VII) Overrun}

A cylinder of fixed volume $(270 \mathrm{~mL})$ was used for sampling. Each taro ice product was sampled five times for measurements. The measurement was taken after the ice product sample was melted at room temperature and the volume of the melted liquid was quantified with a measuring cylinder. The overrun was calculated by the following equation ${ }^{(1)}$ :

Overrun $=($ volume before melting-volume after melting $) /$ (volume after melting)

\section{(VIII) Melting Rate}

The method established by Martionou-Voulasiki and Zerfiridis ${ }^{(16)}$ was adopted with minor modifications. The commercial taro ice products were allowed to melt on sieves of 5 mesh after stored at $-20 \pm 1{ }^{\circ} \mathrm{C}$ for $16 \mathrm{hr}$. The resulted melted liquid drained from the sieves was collected and weighed in 10-min intervals. The melting rate for each individual taro ice product was calculated from the slope of the melting curve plotted as time against weight. Each ice product was sampled and measured in triplicate.

\section{(IX) Composition and Content of Free Sugars}

Commercial taro ice products were instantly frozen to $-30^{\circ} \mathrm{C}$ followed by freeze-drying. One gram of the dried sample was weighed and $20 \mathrm{~mL}$ of $75 \%$ alcohol was added. Then the mixture was centrifuged at $1,500 \mathrm{x} \mathrm{g}$ for $10 \mathrm{~min}$. The procedure was repeated for 3 times to extract free sugars. All of the extracts were collected and vacuum concentrated at $50^{\circ} \mathrm{C}$. The concentrate was diluted to $25 \mathrm{~mL}$ in volumetric flask with deionized water. A $10-\mathrm{mL}$ aliquot of the diluted concentrate was passed through anionic resin bed (Amberlite IRA-93, Sigma) followed by diluting to $100 \mathrm{~mL}$ with a volumetric flask. The dilutant was filtered through a $0.45 \mu \mathrm{m}$ membrane then analyzed for free sugars by a high-performance anion-exchange chromatography (Model DX500, Dionex Corp., USA). The separation was carried out by injecting the sample dilutant onto a Dionex CarboPac ${ }^{\mathrm{TM}}$ PA1 analytical column $(4 \times 250 \mathrm{~mm})$ followed by elution. Eluents $\mathrm{A}$ and $\mathrm{B}$ were $50 \mathrm{mM}$ sodium hydroxide $(\mathrm{NaOH})$ and $50 \mathrm{mM} \mathrm{NaOH} / 100 \mathrm{mM}$ sodium acetate $\left(\mathrm{CH}_{3} \mathrm{COONa}\right)$, respectively. The procedure for concentration gradients was programmed to contain eluent $\mathrm{B}$ as follows: $4 \%$ for $0 \mathrm{~min}$, $4 \%$ for $15 \mathrm{~min}$ and $40 \%$ for $30 \mathrm{~min}$ at flow rate of 0.8 $\mathrm{mL} / \mathrm{min}$. Each ice product was sampled 3 times and the analysis was performed in triplicate.

\section{(X) Statistical Analysis}

Data were analyzed by the Statistical Analysis System $(\mathrm{SAS})^{(17)}$. Analysis of variance (ANOVA), correlation analysis, Duncan's multiple rang test, and principal component analysis (PCA) were performed as appropriate ${ }^{(11,18)}$.

\section{RESULTS AND DISCUSSION}

\section{Sensory Evaluation}

Fourteen market available taro ice products were collected for the present study and were separated in to two categories, i.e., ice bar products and ice cream products. By the order of sampling, the samples were labeled with the letters A-H and I-N for ice bar and ice cream products, respectively, then subjected to sensory evaluation. The statistical analyses are summarized in Table 1. The differences among samples were statistically significant $(p<0.001)$ for all evaluated

Table 1. Analyses of variance of the descriptive attribute ratings (12 judges): degrees of freedom (df), $\mathrm{F}$ ratios, and error mean squares (MSE)

\begin{tabular}{lcccc}
\hline & \multicolumn{4}{c}{ F-ratios } \\
\cline { 2 - 5 } & Panelist & Replication & Product & MSE \\
\hline Firmness & $3.41^{\mathrm{b}}$ & 0.02 & $13.46^{\mathrm{c}}$ & 3.45 \\
Taro flavor & $6.21^{\mathrm{c}}$ & 0.95 & $15.52^{\mathrm{c}}$ & 3.17 \\
Sweetness & $3.31^{\mathrm{b}}$ & 1.52 & $14.39^{\mathrm{c}}$ & 1.59 \\
Color & $3.10^{\mathrm{b}}$ & 1.14 & $19.20^{\mathrm{c}}$ & 3.36 \\
Creaminess & $4.98^{\mathrm{b}}$ & 1.01 & $14.17^{\mathrm{c}}$ & 2.41 \\
Thickness & $7.27^{\mathrm{c}}$ & $3.89^{\mathrm{a}}$ & $8.10^{\mathrm{c}}$ & 1.84 \\
Fattiness & $8.45^{\mathrm{c}}$ & $6.37^{\mathrm{a}}$ & $12.27^{\mathrm{c}}$ & 1.64 \\
Overall score & $2.46^{\mathrm{a}}$ & 2.52 & $22.47^{\mathrm{c}}$ & 7.18 \\
\hline df & 11 & 1 & 13 & 143 \\
\hline a b, c & & 1 & & 13
\end{tabular}

a, b, c Significant at 5\%, $1 \%$ and $0.1 \%$ levels, respectively. 
attributes. Only ratings to the taro flavor, thickness, and fattiness showed significant inter-panelist difference $(\mathrm{p}<0.001)$. Variations among panelists to these sensory attributes are common and are considered acceptable in descriptive sensory analysis ${ }^{(10)}$. Because the rating to a given attribute was significantly different among samples, the panelists had demonstrated good agreement after appropriate training. Besides, the differences between replications of any given attribute rated by the same panelist were less significant compared to inter-samples and inter-panelists (Table 1).

The results of sensory evaluation are shown in Table 2. Except for sample N (4.12), the scores to firmness of the taro ice cream products $(2.57-3.77)$ were significantly lower than those to the taro ice bar products $(3.97-6.77)(\mathrm{p}<0.05)$, indicating that the firmness of ice products is largely determined by the types of the products. The flavor of taro ice products were at lower scores $(\leq 4.17)$, with the exception of samples A (5.64) and $\mathrm{H}$ (5.32), which suggests that this sensory char- acteristic in the commercial taro ice products, especially for taro ice cream products, was not satisfied by the panelists. Despite the proportion of taro raw material contained in the products, it is speculated to be affected by the heat treatment during raw material processing that might result in severe flavor evaporation $^{(19)}$. The scores of the sweetness and creaminess were more consistent for the ice bar products, whereas those to the ice cream products were more diverse. On the contrary, the color and thickness scores were less diverse for the ice cream products. The ice bar products were evaluated to be less greasy with better mouthfeel properties, as shown by the lower fattiness scores. The ice bar products also received higher overall scores, indicating that the overall liking favored the ice bar products over the ice cream products.

\section{Physicochemical Analysis}

The texture properties of the taro ice products were ana-

Table 2. Sensory evaluation on commercial taro ice products

\begin{tabular}{|c|c|c|c|c|c|c|c|c|}
\hline Product & Firmness & Taro flavor & Sweetness & Color & Creaminess & Thickness & Fattiness & Overall score \\
\hline \multicolumn{9}{|l|}{ Ice bar } \\
\hline A & $5.82^{b *}$ & $5.64^{\mathrm{a}}$ & $5.91^{\mathrm{ab}}$ & $5.45^{\mathrm{ab}}$ & $3.55^{\mathrm{g}}$ & $5.45^{\mathrm{ab}}$ & $2.27^{\mathrm{d}}$ & $5.91^{b}$ \\
\hline B & $4.67^{\text {cde }}$ & $3.20^{\mathrm{b}}$ & $4.50^{\mathrm{cd}}$ & $3.58^{\mathrm{cd}}$ & $6.17^{\mathrm{bc}}$ & $4.58^{\mathrm{bcd}}$ & $4.17^{\mathrm{bc}}$ & $3.75^{\mathrm{e}}$ \\
\hline $\mathrm{C}$ & $5.00^{\text {bcd }}$ & $3.50^{\mathrm{b}}$ & $4.58^{\mathrm{cd}}$ & $5.17^{\mathrm{ab}}$ & $4.50^{\mathrm{ef}}$ & $4.33^{\text {cde }}$ & $4.50^{\mathrm{bc}}$ & $4.42^{\mathrm{de}}$ \\
\hline $\mathrm{D}$ & $4.75^{\mathrm{cde}}$ & $3.50^{\mathrm{b}}$ & $4.42^{\mathrm{cd}}$ & $4.00^{c}$ & $5.00^{\mathrm{def}}$ & $4.42^{\mathrm{cd}}$ & $3.83^{\mathrm{c}}$ & $4.00^{\mathrm{de}}$ \\
\hline $\mathrm{E}$ & $4.67^{\text {cde }}$ & $3.50^{\mathrm{b}}$ & $4.75^{\mathrm{cd}}$ & $5.17^{\mathrm{ab}}$ & $4.92^{\mathrm{def}}$ & $3.92^{\mathrm{de}}$ & $3.92^{\mathrm{c}}$ & $3.83^{\mathrm{de}}$ \\
\hline $\mathrm{F}$ & $5.50^{\mathrm{bc}}$ & $3.95^{b}$ & $4.55^{\mathrm{cd}}$ & $1.90^{\mathrm{e}}$ & $4.20^{\mathrm{fg}}$ & $4.55^{\mathrm{bcd}}$ & $4.20^{\mathrm{bc}}$ & $5.35^{\mathrm{bc}}$ \\
\hline G & $6.77^{\mathrm{a}}$ & $4.03^{b}$ & $6.37^{\mathrm{a}}$ & $6.25^{\mathrm{a}}$ & $6.83^{\mathrm{ab}}$ & $6.06^{\mathrm{a}}$ & $5.38^{\mathrm{ab}}$ & $4.67^{\mathrm{cd}}$ \\
\hline $\mathrm{H}$ & $3.97^{\mathrm{def}}$ & $5.32^{\mathrm{a}}$ & $4.08^{d}$ & $2.72^{\mathrm{de}}$ & $5.67^{\mathrm{cd}}$ & $5.18^{\mathrm{abc}}$ & $4.05^{\mathrm{c}}$ & $6.92^{\mathrm{a}}$ \\
\hline \multicolumn{9}{|l|}{ Ice cream } \\
\hline I & $2.57^{\mathrm{h}}$ & $1.73^{c}$ & $5.25^{\mathrm{bc}}$ & $5.07^{\mathrm{b}}$ & $5.70^{\mathrm{cd}}$ & $3.43^{\mathrm{e}}$ & $6.48^{\mathrm{a}}$ & $2.35^{\mathrm{fg}}$ \\
\hline $\mathrm{J}$ & $3.77^{\mathrm{efg}}$ & $1.77^{\mathrm{c}}$ & $2.73^{\mathrm{e}}$ & $2.12^{\mathrm{e}}$ & $3.53^{\mathrm{g}}$ & $2.47^{\mathrm{f}}$ & $4.42^{\mathrm{bc}}$ & $1.75^{\mathrm{g}}$ \\
\hline $\mathrm{K}$ & $2.52^{\mathrm{h}}$ & $0.92^{\mathrm{c}}$ & $5.15^{\text {bcd }}$ & $6.03^{\mathrm{ab}}$ & $7.12^{\mathrm{a}}$ & $4.48^{\mathrm{cd}}$ & $5.77^{\mathrm{a}}$ & $2.32^{\mathrm{fg}}$ \\
\hline $\mathrm{L}$ & $2.92^{\mathrm{gh}}$ & $3.28^{\mathrm{b}}$ & $4.16^{\mathrm{cd}}$ & $5.03^{\mathrm{b}}$ & $5.67^{\mathrm{cd}}$ & $4.18^{\mathrm{de}}$ & $6.05^{\mathrm{a}}$ & $2.92^{\mathrm{f}}$ \\
\hline M & $3.42^{\text {fgh }}$ & $4.17^{\mathrm{b}}$ & $5.13^{b c d}$ & $5.11^{\mathrm{b}}$ & $4.83^{\mathrm{def}}$ & $4.17^{\mathrm{de}}$ & $3.72^{c}$ & $4.58^{\mathrm{cde}}$ \\
\hline $\mathrm{N}$ & $4.12^{\mathrm{def}}$ & $3.85^{\mathrm{b}}$ & $4.78^{\mathrm{cd}}$ & $6.12^{\mathrm{ab}}$ & $5.22^{\mathrm{de}}$ & $4.31^{\mathrm{cde}}$ & $4.13^{c}$ & $4.35^{\mathrm{de}}$ \\
\hline
\end{tabular}

* Means within column with different letters are significantly different at $5 \%$ level.

Table 3. Texture profile parameters of commercial taro ice products

\begin{tabular}{|c|c|c|c|c|c|c|}
\hline \multirow[b]{2}{*}{ Product } & \multicolumn{4}{|c|}{ Primary parameter } & \multicolumn{2}{|c|}{ Secondary parameter } \\
\hline & $\begin{array}{l}\text { Firmness } \\
\text { (g-force) }\end{array}$ & Springiness & Cohesiveness & $\begin{array}{c}\text { Adhesiveness } \\
\text { (g-force) }\end{array}$ & $\begin{array}{c}\text { Chewiness } \\
\text { (g-force) }\end{array}$ & $\begin{array}{c}\text { Gumminess } \\
\text { (g-force) }\end{array}$ \\
\hline \multicolumn{7}{|l|}{ Ice bar } \\
\hline A & $4596 \pm 167^{a}$ & $0.65 \pm 0.05$ & $0.025 \pm 0.005$ & $-35.5 \pm 1.3$ & $74.9 \pm 2.9$ & $114.6 \pm 0.5$ \\
\hline B & $5883 \pm 124$ & $0.70 \pm 0.05$ & $0.008 \pm 0.002$ & $-23.0 \pm 0.3$ & $32.9 \pm 1.1$ & $47.3 \pm 0.8$ \\
\hline $\mathrm{C}$ & $7728 \pm 367$ & $0.84 \pm 0.02$ & $0.066 \pm 0.011$ & $-30.6 \pm 0.5$ & $262.8 \pm 2.9$ & $312.2 \pm 0.5$ \\
\hline $\mathrm{D}$ & $4952 \pm 323$ & $0.64 \pm 0.03$ & $0.025 \pm 0.006$ & $-57.0 \pm 1.0$ & $79.4 \pm 1.4$ & $123.8 \pm 2.7$ \\
\hline $\mathrm{E}$ & $4930 \pm 436$ & $0.56 \pm 0.05$ & $0.029 \pm 0.006$ & $-40.2 \pm 0.7$ & $69.6 \pm 2.5$ & $124.0 \pm 0.6$ \\
\hline $\mathrm{F}$ & $4879 \pm 212$ & $0.57 \pm 0.03$ & $0.034 \pm 0.004$ & $-41.9 \pm 0.2$ & $94.4 \pm 3.0$ & $166.2 \pm 2.1$ \\
\hline $\mathrm{G}$ & $3698 \pm 152$ & $0.99 \pm 0.02$ & $0.040 \pm 0.008$ & $-19.6 \pm 1.4$ & $188.7 \pm 1.6$ & $189.9 \pm 2.0$ \\
\hline $\mathrm{H}$ & $4403 \pm 338$ & $0.85 \pm 0.03$ & $0.035 \pm 0.005$ & $-32.8 \pm 0.4$ & $180.0 \pm 1.9$ & $227.9 \pm 2.6$ \\
\hline \multicolumn{7}{|l|}{ Ice cream } \\
\hline I & $2447 \pm 206$ & $0.52 \pm 0.01$ & $0.027 \pm 0.003$ & $-21.4 \pm 0.1$ & $40.8 \pm 0.6$ & $74.0 \pm 0.6$ \\
\hline $\mathrm{J}$ & $3268 \pm 69$ & $0.45 \pm 0.03$ & $0.078 \pm 0.006$ & $-35.0 \pm 1.8$ & $50.0 \pm 1.5$ & $74.8 \pm 0.4$ \\
\hline $\mathrm{K}$ & $2734 \pm 66$ & $0.69 \pm 0.01$ & $0.055 \pm 0.001$ & $-41.9 \pm 1.2$ & $48.1 \pm 0.6$ & $90.8 \pm 0.9$ \\
\hline $\mathrm{L}$ & $1285 \pm 86$ & $0.60 \pm 0.01$ & $0.038 \pm 0.001$ & $-36.2 \pm 1.1$ & $29.5 \pm 0.8$ & $48.8 \pm 0.6$ \\
\hline M & $2666 \pm 138$ & $0.58 \pm 0.01$ & $0.042 \pm 0.003$ & $-47.7 \pm 2.0$ & $38.7 \pm 0.2$ & $63.5 \pm 1.3$ \\
\hline $\mathrm{N}$ & $3937 \pm 166$ & $0.61 \pm 0.01$ & $0.038 \pm 0.001$ & $-33.5 \pm 1.8$ & $32.9 \pm 0.1$ & $89.7 \pm 1.4$ \\
\hline
\end{tabular}

\footnotetext{
a Values are means \pm standard deviations.
} 
lyzed by using of a texture analyzer. The results showed that among the primary parameters, the firmness scores were higher for the ice bar products (3698-7728) than the ice cream products (1285-3937) (Table 3), giving excellent correlation with sensory ratings (Table 2 ). As for the springiness, cohesiveness, and adhesiveness, there were no pattern to follow, mostly depending on the individual sample per se. The chewiness and gumminess were the secondary parameters derived from the primary parameters. The scores of these particular parameters were higher in the ice bar products than the ice cream products. Because incorporation of air is not required for ice bar as what was needed in the ice cream products to enhance the overrun parameter, this might partially explain the increased firmness presented in the ice bar products. In addition, the lacking of requirements for standards of identity for ice bar products provides the manufactures liberty to add non-homogenized solids to diversify the mouthfeel properties of the products. The reason might have contributed to the firmer texture demonstrated by the ice bar products. In contrast, due to the legal standard regulated composition and the high overrun properties required by the ice cream products, the firmness measured by the simulated chewing action would be lower compared to the ice bar products. Additionally, the lower energy required for chewing-swallowing motions and the smaller and evener homogenized solids embedded in the ice cream may provide explanations for the lower chewiness and gumminess scores measured from the ice cream products.

The color of the ice products is a strong reflection of their compositions. This is particularly true when artificial food coloring agents such as Blue No. 1, Red No. 6 and 7, or Yellow No. 4 and 5 were added to the products. The color measured from the ice bar products were darker than the ice cream products, indicating that the brightness is stronger in the ice cream products as represented by the higher Hunter $\mathrm{L}$ values (Table 4 ). The Hunter values $\mathrm{a}$ and $\mathrm{b}$ for taro ice bar products were in the range of +0.31 to +4.14 and -0.24 to +3.55 , respectively, and the color index (E values) were in the range of 26.5 to 41.4 . In comparison, the $\mathrm{a}, \mathrm{b}$, and $\mathrm{E}$ values for the ice cream products were in the range of +0.41 to $+1.93,-2.39$ to +2.53 , and 37.5 to 47.9 , respectively. It is then apparent from the value distributions that the color differences were greater among the taro ice bar products. This may be due to the less homogenized solids in the ice bar products.

The moisture content of the taro ice products was between $61.39 \%$ and $81.01 \%$ (Table 5). The fat content was higher in the ice cream products (Table 5). The viscosity of the ice products after melting varied with the brands. In general, the viscosity showed a positive correlation with the content of crude fat in the ice cream products $(p<0.05)$, whereas there was no significant correlation demonstrated by the ice bar products (Table 5). Budiaman and Fennema ${ }^{(20,21)}$ suggest that the viscosity of ice cream is significantly influenced by the air bubbles. In other words, the stability of the air bub-

Table 4. Color values of commercial taro ice products

\begin{tabular}{ccccc}
\hline Product & $\mathrm{L}$ & $\mathrm{a}$ & $\mathrm{b}$ & $\mathrm{E}$ \\
\hline Ice bar & & & & \\
$\mathrm{A}$ & $26.30 \pm 0.22^{* \mathrm{f}^{* *}}$ & $1.50 \pm 0.08^{\mathrm{cd}}$ & $2.53 \pm 0.20^{\mathrm{b}}$ & 26.5 \\
$\mathrm{~B}$ & $37.68 \pm 6.52^{\mathrm{cd}}$ & $1.02 \pm 0.37^{\mathrm{e}}$ & $3.55 \pm 0.64^{\mathrm{a}}$ & 37.9 \\
$\mathrm{C}$ & $36.02 \pm 2.35^{\mathrm{de}}$ & $1.80 \pm 0.52^{\mathrm{bc}}$ & $-0.24 \pm 0.10^{\mathrm{d}}$ & 36.1 \\
$\mathrm{D}$ & $37.52 \pm 2.75^{\mathrm{cd}}$ & $0.53 \pm 0.09^{\mathrm{f}}$ & $2.13 \pm 0.36^{\mathrm{b}}$ & 37.6 \\
$\mathrm{E}$ & $41.35 \pm 1.51^{\mathrm{b}}$ & $1.12 \pm 0.16^{\mathrm{e}}$ & $-1.11 \pm 0.08^{\mathrm{e}}$ & 41.4 \\
$\mathrm{~F}$ & $26.31 \pm 0.06^{\mathrm{f}}$ & $1.34 \pm 0.29^{\mathrm{ed}}$ & $2.49 \pm 0.20^{\mathrm{b}}$ & 26.5 \\
$\mathrm{G}$ & $40.11 \pm 0.58^{\mathrm{bc}}$ & $4.14 \pm 0.10^{\mathrm{a}}$ & $-2.34 \pm 0.19^{\mathrm{g}}$ & 40.4 \\
$\mathrm{H}$ & $33.53 \pm 0.55^{\mathrm{e}}$ & $0.31 \pm 0.05^{\mathrm{f}}$ & $1.47 \pm 0.35^{\mathrm{c}}$ & 33.6 \\
\hline Ice cream & & & & \\
$\mathrm{I}$ & $47.88 \pm 0.01^{\mathrm{a}}$ & $1.93 \pm 0.05^{\mathrm{b}}$ & $-1.45 \pm 0.05^{\mathrm{ef}}$ & 47.9 \\
$\mathrm{~J}$ & $37.41 \pm 0.59^{\mathrm{cd}}$ & $0.41 \pm 0.04^{\mathrm{f}}$ & $2.53 \pm 0.09^{\mathrm{b}}$ & 37.5 \\
$\mathrm{~K}$ & $47.73 \pm 0.20^{\mathrm{a}}$ & $1.82 \pm 0.02^{\mathrm{bc}}$ & $-1.38 \pm 0.12^{\mathrm{ef}}$ & 47.8 \\
$\mathrm{~L}$ & $46.13 \pm 0.22^{\mathrm{a}}$ & $1.28 \pm 0.01^{\mathrm{ed}}$ & $-2.39 \pm 0.04^{\mathrm{g}}$ & 46.2 \\
$\mathrm{M}$ & $47.68 \pm 0.16^{\mathrm{a}}$ & $1.25 \pm 0.03^{\mathrm{ed}}$ & $-1.59 \pm 0.07^{\mathrm{f}}$ & 47.7 \\
$\mathrm{~N}$ & $47.45 \pm 0.13^{\mathrm{a}}$ & $1.32 \pm 0.01^{\mathrm{ed}}$ & $-1.11 \pm 0.13^{\mathrm{e}}$ & 47.5 \\
\hline
\end{tabular}

* Values are means \pm standard deviations.

**Means within column with different letters are significantly different at $5 \%$ level.

Table 5. Some properties of commercial taro ice products

\begin{tabular}{|c|c|c|c|c|c|}
\hline Product & Water $(\%)$ & Crude fat $(\%)$ & Viscosity (cps) & Overrun & Melting rate $(\mathrm{g} / \mathrm{min})$ \\
\hline \multicolumn{6}{|l|}{ Ice bar } \\
\hline A & $75.28 \pm 0.15^{\mathrm{a}}$ & $0.04 \pm 0.00$ & $1800 \pm 150$ & $0.13 \pm 0.08$ & $0.51 \pm 0.03$ \\
\hline B & $64.57 \pm 0.18$ & $6.24 \pm 0.09$ & $2650 \pm 274$ & $0.11 \pm 0.06$ & $0.98 \pm 0.06$ \\
\hline $\mathrm{C}$ & $66.98 \pm 0.32$ & $2.22 \pm 0.04$ & $321 \pm 18$ & $0.49 \pm 0.09$ & $0.88 \pm 0.01$ \\
\hline $\mathrm{D}$ & $77.24 \pm 0.17$ & $1.08 \pm 0.01$ & $3220 \pm 325$ & $0.18 \pm 0.08$ & $0.49 \pm 0.02$ \\
\hline $\mathrm{E}$ & $70.85 \pm 0.04$ & $3.74 \pm 0.09$ & $267 \pm 15$ & $0.54 \pm 0.11$ & $1.02 \pm 0.11$ \\
\hline $\mathrm{F}$ & $72.62 \pm 0.04$ & $0.14 \pm 0.00$ & $2390 \pm 158$ & $0.07 \pm 0.01$ & $0.31 \pm 0.01$ \\
\hline G & $61.39 \pm 0.11$ & $1.65 \pm 0.01$ & $87 \pm 17$ & $0.62 \pm 0.04$ & $0.75 \pm 0.03$ \\
\hline $\mathrm{H}$ & $75.85 \pm 0.04$ & $0.18 \pm 0.02$ & $3640 \pm 315$ & $0.05 \pm 0.01$ & $0.67 \pm 0.05$ \\
\hline \multicolumn{6}{|l|}{ Ice cream } \\
\hline I & $66.24 \pm 0.02$ & $10.33 \pm 0.01$ & $1650 \pm 131$ & $0.81 \pm 0.21$ & $0.98 \pm 0.06$ \\
\hline $\mathrm{J}$ & $81.01 \pm 0.12$ & $1.64 \pm 0.01$ & $144 \pm 12$ & $0.76 \pm 0.19$ & $0.52 \pm 0.03$ \\
\hline $\mathrm{K}$ & $70.72 \pm 0.16$ & $5.35 \pm 0.05$ & $256 \pm 141$ & $1.63 \pm 0.12$ & $1.10 \pm 0.02$ \\
\hline $\mathrm{L}$ & $62.76 \pm 0.01$ & $7.61 \pm 0.03$ & $1270 \pm 141$ & $2.05 \pm 0.23$ & $1.03 \pm 0.05$ \\
\hline M & $63.12 \pm 0.03$ & $7.49 \pm 0.04$ & $1120 \pm 104$ & $2.48 \pm 0.08$ & $0.97 \pm 0.03$ \\
\hline $\mathrm{N}$ & $65.83 \pm 0.04$ & $7.22 \pm 0.03$ & $1230 \pm 98$ & $1.87 \pm 0.10$ & $1.13 \pm 0.05$ \\
\hline
\end{tabular}

\footnotetext{
a Values are means \pm standard deviations.
} 
bles incorporated in ice cream after melting is the determining factor for the presented viscosity of the ice cream. Because the fat content has an effect on the stability of the air bubbles, it is also correlative with the viscosity of the ice cream.

The overrun values were in the range of 0.13 to 0.62 and 0.76 to 2.48 , respectively, for the ice bar and ice cream products (Table 5). The differences were primarily due to the different production means of various product types. Ice cream products emphasize on the instant melting and homogenous properties whereas the ice bar products emphasized on reaching certain level of firmness. Because most of the ice bar products consisted of heterogeneous solids that left larger pieces on the sieves, which was in contrast to the free flow liquid demonstrated by the ice cream products. As a consequence, the melting rates of the ice cream products were faster than the ice bar products. However, the composition of the products, such as the content of fat, also plays a part in the rate of melting ${ }^{(16)}$. Therefore, the measured melting rates did not completely follow the classification of the ice products (Table 5).

Only limited sweeteners are ever used in ice products. Of which sucrose, corn syrup and malt syrup are the most commonly seen ${ }^{(1)}$. Based on the free sugars measured from the samples, sucrose was the major sweetener employed for the commercial taro ice products collected in the present study, followed by lactose (Table 6). It is likely that the lactose tested from the samples were from the dairy components of the ice products. Thereby, the major sweetener used in commercial taro ice products, at least for those analyzed in the present study, was sucrose.

\section{Correlation Analysis}

In order to determine the correlation between the physicochemical properties and the sensory ratings, correlation analysis was performed on the results obtained from the physicochemical analysis and the sensory evaluation ${ }^{(17)}$. The data showed that the moisture content was positively correlated with the firmness $(\mathrm{p}<0.05)$ but was negatively correlated with the color and creaminess $(p<0.05)$. Because the size of ice crystals is inversely proportional to the content of total solids ${ }^{(10)}$, and because the texture of the ice products is directly affected by the size of the ice crystals ${ }^{(22)}$, the firmness and creaminess properties can be affected by the moisture content of the ice products. The content of crude fats correlated with the firmness $(\mathrm{p}<0.01)$ and the overall rating $(\mathrm{p}<0.05)$ in negative manners, but in a positive manner with the fattiness $(p<0.05)$. These results were in agreement with Guinard et al. ${ }^{(10)}$, who showed that the content of sugars added to the ice products affected sensory ratings such as fattiness and creaminess, and oppositely affected the firmness of the ice products. The present study measured the content of 5 free sugars in the ice products and the sum of the 5 sugars was presented as the content of total free sugars (Table 6). Statistical analysis showed that the total free sugar content was in negative correlation with the firmness of the ice products $(\mathrm{p}<0.05)$ but was in positive correlation with the color $(\mathrm{p}<0.01)$, creaminess $(\mathrm{p}<0.05)$, and fattiness $(\mathrm{p}<0.05)$ (Table $7)$. The overrun of the ice products was inversely correlated with the firmness $(\mathrm{p}<0.05)$, whereas the melting rate was corrected with the color and creaminess $(\mathrm{p}<0.05)$ (Table 7$)$.

\section{Principal Component Analysis}

As demonstrated by Table 7, it was clearly demonstrated that the overall acceptability of an ice product is compounded by many factors, which is not easily expressed by a simple liner regression equation. This conclusion is consistent with studies conducted in vanilla ice cream ${ }^{(10)}$. Therefore, principal component analysis ${ }^{(10,13,18,23)}$ was performed to evaluate the correlation between sensory ratings and texture parameters on the ice bar and ice cream products.

The primary and secondary principal components accounted for 40.04 and $28.33 \%$, respectively, of variance of the descriptive sensory ratings of the ice bar products (Figure

Table 6. Free sugar contents (mg/g of dry matter) of commercial taro ice products

\begin{tabular}{|c|c|c|c|c|c|c|}
\hline Product & Glucose & Sucrose & Fructose & Maltose & Lactose & Total free sugar \\
\hline \multicolumn{7}{|l|}{ Ice bar } \\
\hline A & $0.52 \pm 0.01^{\mathrm{a}}$ & $3.87 \pm 0.01$ & $0.20 \pm 0.01$ & $1.87 \pm 0.02$ & $2.02 \pm 0.02$ & $8.48^{c}$ \\
\hline $\mathrm{B}$ & $0.25 \pm 0.01$ & $6.74 \pm 0.02$ & $0.29 \pm 0.01$ & $0.05 \pm 0.01$ & $5.58 \pm 0.03$ & 12.91 \\
\hline $\mathrm{C}$ & $1.29 \pm 0.02$ & $7.79 \pm 0.02$ & $0.29 \pm 0.01$ & $3.39 \pm 0.01$ & $2.40 \pm 0.02$ & 15.16 \\
\hline $\mathrm{D}$ & $0.85 \pm 0.01$ & $4.20 \pm 0.01$ & $0.14 \pm 0.01$ & $0.19 \pm 0.01$ & $3.27 \pm 0.01$ & 8.65 \\
\hline $\mathrm{E}$ & $0.69 \pm 0.01$ & $8.27 \pm 0.01$ & $0.09 \pm 0.01$ & $2.26 \pm 0.01$ & $2.08 \pm 0.01$ & 13.39 \\
\hline $\mathrm{F}$ & $0.46 \pm 0.01$ & $3.83 \pm 0.01$ & $0.51 \pm 0.01$ & $0.31 \pm 0.01$ & $2.03 \pm 0.01$ & 7.14 \\
\hline $\mathrm{G}$ & $0.44 \pm 0.01$ & $11.45 \pm 0.03$ & $0.29 \pm 0.01$ & $2.80 \pm 0.02$ & - & 14.98 \\
\hline $\mathrm{H}$ & $0.14 \pm 0.01$ & $2.72 \pm 0.01$ & $0.22 \pm 0.01$ & $0.01 \pm 0.01$ & $5.08 \pm 0.03$ & 8.17 \\
\hline \multicolumn{7}{|l|}{ Ice cream } \\
\hline I & $0.57 \pm 0.01$ & $10.19 \pm 0.05$ & $0.06 \pm 0.01$ & $2.16 \pm 0.01$ & $2.03 \pm 0.05$ & 15.01 \\
\hline $\mathrm{J}$ & $0.67 \pm 0.01$ & $4.55 \pm 0.01$ & $0.10 \pm 0.01$ & $0.05 \pm 0.01$ & $2.42 \pm 0.02$ & 7.79 \\
\hline $\mathrm{K}$ & $2.70 \pm 0.02$ & $-^{\mathrm{b}}$ & $0.56 \pm 0.01$ & $3.16 \pm 0.02$ & $15.08 \pm 0.05$ & 21.50 \\
\hline $\mathrm{L}$ & $0.76 \pm 0.01$ & $8.29 \pm 0.03$ & $0.15 \pm 0.01$ & $0.87 \pm 0.01$ & $1.56 \pm 0.01$ & 11.63 \\
\hline M & $2.33 \pm 0.01$ & $1.21 \pm 0.02$ & $0.74 \pm 0.01$ & $0.89 \pm 0.01$ & $5.77 \pm 0.01$ & 10.94 \\
\hline $\mathrm{N}$ & $5.01 \pm 0.03$ & $0.08 \pm 0.01$ & $0.85 \pm 0.01$ & $0.51 \pm 0.01$ & $8.13 \pm 0.02$ & 14.58 \\
\hline
\end{tabular}

a Values are means \pm standard deviations. $\quad{ }^{b}$ Undetectable. $\quad{ }^{c}$ Total free sugar $=$ glucose + sucrose + fructose + maltose + lactose. 
Table 7. Correlation analysis on the physicochemical properties and sensory evaluation of commercial taro ice products

\begin{tabular}{lcccccc}
\hline & \multicolumn{5}{c}{ Physicochemical properties } \\
\cline { 2 - 7 } Sensory evaluation & Water & Crude fat & Total free sugar & Viscosity & Overrun & Melting rate \\
\hline Firmness & $0.661^{\mathrm{a}}$ & $-0.740^{\mathrm{b}}$ & $-0.641^{\mathrm{a}}$ & 0.033 & $-0.560^{\mathrm{a}}$ & $-0.529^{\mathrm{a}}$ \\
Taro flavor & -0.045 & -0.426 & -0.388 & 0.331 & -0.086 & -0.125 \\
Sweetness & -0.514 & 0.025 & 0.414 & -0.145 & 0.088 & 0.177 \\
Color & $-0.598^{\mathrm{a}}$ & 0.407 & $0.687^{\mathrm{b}}$ & -0.499 & 0.510 & $0.660^{\mathrm{a}}$ \\
Creaminess & $-0.549^{\mathrm{a}}$ & 0.388 & $0.703^{\mathrm{b}}$ & -0.045 & 0.292 & $0.570^{\mathrm{a}}$ \\
Thickness & -0.277 & -0.473 & 0.073 & 0.244 & -0.127 & -0.127 \\
Fattiness & -0.437 & $0.582^{\mathrm{a}}$ & $0.538^{\mathrm{a}}$ & -0.302 & 0.400 & 0.447 \\
Overall score & 0.069 & $-0.644^{\mathrm{a}}$ & -0.403 & 0.515 & -0.308 & -0.382 \\
\hline
\end{tabular}

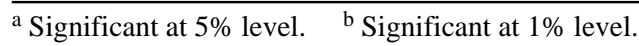

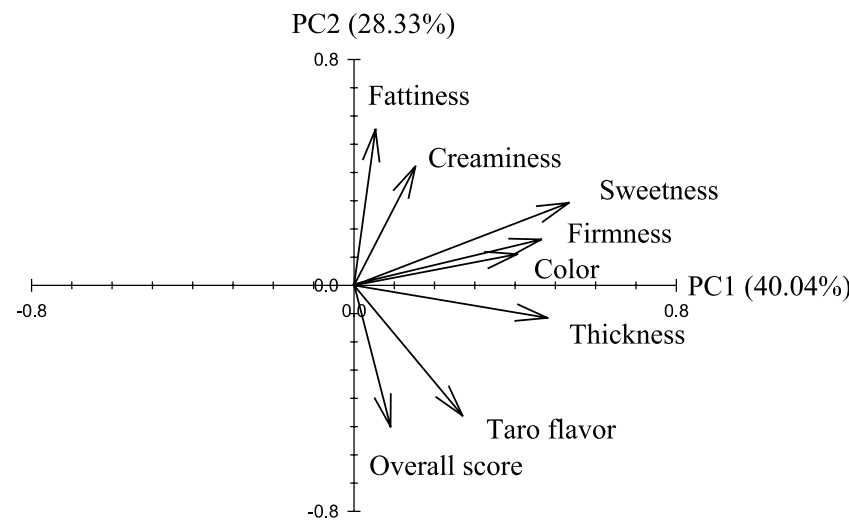

Figure 1. Vector plot for the first and second components of the principal component analysis on sensory evaluation of commercial taro icebar products.

1). The tertiary principal component accounted for $17.57 \%$ of variance (data not shown), also. Based on these results, the quality of ice bar products are affected by complex factors so that it is difficult to be described by sensory evaluation. This might be explained by the great variation in the compositions of the ice bar products and also the sensory items evaluated in the present study did not cover all of the characteristics carried by the ice products. The evaluated sensory items that significantly $(\mathrm{p}<0.05)$ affected the primary principal component were sweetness (vector value= $0.5330)$, thickness (0.4822), firmness (0.4623) and color (0.4045). Other sensory items only slightly attributed to the primary principal component and did not reach significance. As to the secondary principal component, fattiness $(0.5540)$ was the significant affecting factor $(\mathrm{p}<0.05)$ whereas other evaluated sensory items did not significantly affect the secondary principal component ( $\mathrm{p}>0.05)$.

Further investigation was carried out on the sensory attributes that significantly $(\mathrm{p}<0.05)$ affected the primary or secondary principal components. The following regression equations were obtained to represent the correlation:

$$
\begin{aligned}
& \mathrm{Pc} 1(\text { ice bar })=0.95 \mathrm{X} 3+0.86 \mathrm{X} 6+0.83 \mathrm{X} 1+0.72 \mathrm{X} 4+\mathrm{R} \\
& \mathrm{Pc} 2 \text { (ice bar) }=0.83 \mathrm{X} 7+\mathrm{R}
\end{aligned}
$$

where Pc1 and Pc2 were the primary and secondary principal components, respectively; X1, X3, X4, X6, X7 and

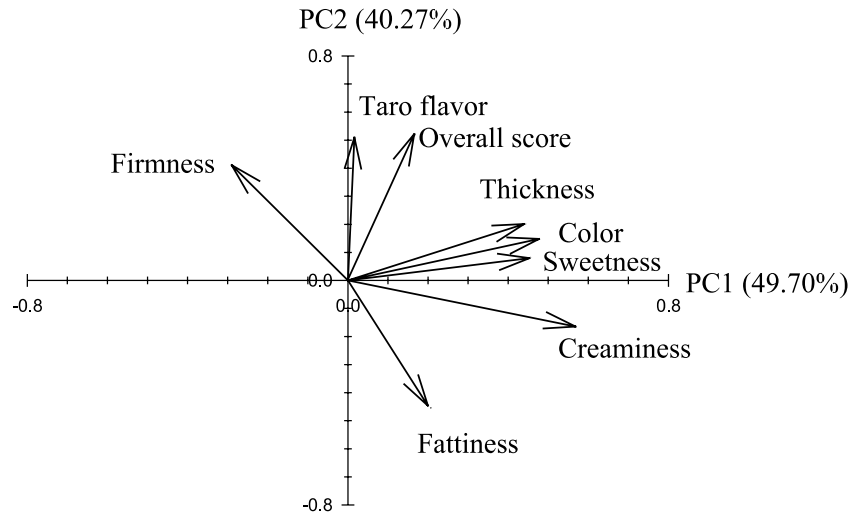

Figure 2. Vector plot for the first and second components of the principal component analysis on sensory evaluation of commercial taro icecream products.

$\mathrm{R}$ were the firmness, sweetness, color, thickness, fattiness and the remaining evaluated sensory properties.

The primary and secondary principal components accounted for 49.70 and $40.27 \%$, respectively, of variance of the descriptive sensory ratings of the ice bar products (Figure 2). The tertiary principal component only accounted for $4.53 \%$ of variance (data not shown), also. In other words, the differences among ice cream products were more likely to be distinguished by the sensory evaluation. The evaluated sensory items that significantly $(\mathrm{p}<0.05)$ affected the primary principal component were color (vector value $=0.4735$ ), creaminess (0.4679), sweetness (0.4552) and thickness (0.4429). Other sensory items were only minor factors and insignificant factors that attributed to the primary principal component. As to the secondary principal component, the overall liking score $(0.5202)$ and the taro flavor $(0.5092)$ were the significant affecting factor $(\mathrm{p}<0.05)$ whereas other evaluated sensory items did not significantly affect the secondary principal component ( $p>0.05)$.

Similar to the ice bar products, the ice cream products were further investigated for the correlation between the sensory items that significantly $(\mathrm{p}<0.05)$ affected the primary or secondary principal components. Regression equations were generated to as follows:

$\mathrm{Pc} 1($ ice cream $)=0.94 \mathrm{X} 4+0.93 \mathrm{X} 5+0.91 \mathrm{X} 3+0.88 \mathrm{X} 6+\mathrm{R}$ $\mathrm{Pc} 2($ ice cream $)=0.93 \mathrm{X} 8+0.91 \mathrm{X} 2+\mathrm{R}$ 
where Pc1 and Pc2 were the primary and secondary principal components, respectively; X2, X3, X4, X5, X6, X8 and $\mathrm{R}$ were the taro flavor, sweetness, color, creaminess, thickness, overall liking scores and the remaining evaluated sensory parameters.

The sensory characteristics significantly $(\mathrm{p}<0.05)$ impacted the primary and secondary principal components of the ice bar and ice cream products were compared and summarized. The sweetness, color, and thickness were the three major sensory properties for the primary principal component of both the ice bar and ice cream products, whereas the firmness and creaminess were the important significant contributing factors for the primary principal component of the ice bar and ice cream products, respectively.

\section{ACKNOWLEDGEMENTS}

Financial support provided to this study (grant no. 87FIRD-01-2-n) by the Council of Agriculture, Executive Yuan, ROC, is gratefully acknowledged. We would like to thank Dr. Chwen-Ting Wang for her translation.

\section{REFERENCES}

1. Arbuckle, W. S. 1977. Ice Cream. 3rd ed. AVI Publishing Co., Inc. Westport, CT, USA.

2. FDA. 1976. Frozen desserts definitions and standards of identity, Sect. 20.1 to 20.5. Title I - Food and Drug, Part 2, Sect 2. Food and Drug Administration. Washington, D. C., USA.

3. Chinese National Standard (CNS). 1986. CNS6508, 7522, 7523. National Bureau of Standards, Ministry of Economic Affairs. Taipei, Taiwan, ROC.

4. Lin, I. J., Chang, H. H., Lee, H. S. and Hwau, J. 1996. Reviews on Ice Cream and Ice Products. FIRDI-151S304, Food Industry Research and Development Institute. Hsinchu, Taiwan.

5. Specter, S. E. and Setser, C. S. 1994. Sensory and physical properties of a reduced-calorie frozen dessert system made with milk fat and sucrose substitutes. J. Dairy Sci. 77: 708-701.

6. Conforti, F. D. 1994. Effect of fat content and corn sweeteners on selected sensory attributes and shelf stability of vanilla ice cream. J. Soc. Dairy Technol. 47: 69-75.

7. Fuji, S. 1993. Optimizing sugar blend ratio in ice milk through response surface methodology to satisfy sweetness, stability and softness parameters. Nippon Shokuhin Kogyo Gakkaishi 40: 732-737.
8. Wittinger, S. A. and Smith, D. E. 1986. Effect of sweeteners and stabilizers on selected sensory attributes and shelf life of ice cream. J. Food Sci. 51: 1463-1470.

9. Stampanoni Koeferli, C. R., Piccinali, P. and Sigrist, S. 1996. The influence of fat, sugar and non-fat milk solids on selected taste, flavor and texture parameters of a vanilla ice-cream. Food Qual. Pref. 7: 69-79.

10. Guinard, J. X., Zoumas-More, C., Mori, L., Panyam, D. and Kilara, A. 1997. Sugar and fat effect on sensory properties of ice cream. J. Food Sci. 62: 1087-1094.

11. Jackson, I. E. 1991. A User's Guide to Principal Component Analysis. John Wiley and Sons. New York, USA.

12. Larmond, E. 1977. Laboratory Method for Sensory Evaluation of Food. Publication number 1637, Agriculture Canada. Ottawa, Canada.

13. Chen, A. O. and Chen, S. L. 1993. The sensory and physicochemical analysis of ponkan mandarin quality. J. Chinese Soc. Hort. Sci. 39: 99-113.

14. Bourne, M. C. 1978. Texture profile analysis. Food Technol. 32: 62-66.

15. AOAC. 1984. Official Methods of Analysis of the Association of Official Analytical Chemists. 14th ed. The Association. Washington, D. C., USA.

16. Martinou-Voulasiki, I. S. and Zerfiridis, G. K. 1990. Effect of some stabilizers on texture and sensory characteristics of yogurt ice cream from sheep's milk. J. Food Sci. 55: 703-707.

17. SAS. 1993. SAS User's Guide: Statistics. SAS Institute, Inc. Cary, NC, USA.

18. Jeffers, J. N. R. 1967. Two case studies in the application of principal component analysis. Applied Statistics 16: 225-236.

19. Chang, C. C. 1997. Effects of agitation rate and sucrose concentration on the texture of taro paste. Master thesis, Providence University. Shalu, Taiwan.

20. Budiaman, E. R. and Fennema, O. 1987. Linear rate of water crystallization as influenced by temperature of hydrocolloid suspension. J. Dairy Sci. 70: 534-546.

21. Budiaman, E. R. and Fennema, O. 1987. Linear rate of water crystallization as influenced by viscosity of hydrocolloid suspension. J. Dairy Sci. 70: 547-554.

22. Donhowe, D. P. and Hartel, R. W. 1996. Recrystallization of ice in ice cream during controlled accelerated storage. Intl. Dairy J. 6: 1191-1208.

23. Chen, L. S. and Ou, A. S. 1998. Descriptive analysis of the aroma of pouchung tea. Food Sci. (ROC) 25: 700713. 


\section{市售芋冰品之官能與物理化學分析 \\ 呂廷璋 ${ }^{1}$ 莊志文 ${ }^{2}$ 張永和 ${ }^{2 *}$ \\ 1. 台灣大學 食品科技研究所 台北市基隆路四段 144巷59號 \\ 2. 靜宜大學 食品營養學系 台中縣沙鹿鎮中棲路 200 號}

(收稿：June 19, $2001 ；$ 接受：November 2, 2001)

摘要

本研究針對市售 14 種不同品牌的芋冰品, 依產品形式分為冰嘈（冰棒, 8 品牌) 及冰淇淋 (6 品牌) 雨 類, 分別測定其外觀色澤、水分含量、脂肪含量、膨脹率、黏度、質地、融化速率及游離糖組成等理化性 質, 並以官能品評及主成分分析法探求其重要官能品評指標項目。結果顯示, 整體而言不同品牌冰淇淋類產 品間之色澤差異較小, 膨脹率則較高。而雨類產品中以冰嘈類產品之堅實度較冰淇淋者為高且融化速率較 慢; 冰品之游離糖組成則大多以蔗糖及乳糖為主。官能品評結果顯示, 冰碍類產品之口感堅實度顯著 （ $\mathrm{p}<0.05 ）$ 高於冰淇淋類者; 不同品牌間之甜度與細滑度的品評結果較為一致, 整體感亦普遍高於冰淇淋類 者。進一步分別針對雨類冰品之官能品評結果進行主成分分析, 結果顯示研究中所採之官能品評項目較能評 估出冰淇淋類樣品間之差異。對芋冰碍類主成分分析結果之第一主成分具顯著（ $<<0.05 ）$ 影響程度的官能品 評項目依序為甜度、黏稠感、堅實度、色澤; 對第二主成分具顯著 $(\mathrm{p}<0.05)$ 影響程度的項目則為油淢感。 而對冰淇淋類者的分析結果具顯著 $(\mathrm{p}<0.05)$ 影響程度的官能品評項目則依序為色澤、細滑度、甜度、黏稠 感 (第一主成分) 及整體感、芋香味 (第二主成分)。綜合比較冰碍及冰淇淋類產品之主成分分析結果, 得 知冰品之甜度、色澤及黏稠感等官能品評項目為市售芋冰品官能性質中的差異指標項目, 故應可作為芋冰品 開發時之参考指標。

關鍵詞：芋冰品，市售品，官能品評，主成分分析 